Syracuse University

SURFACE

$1-1-2010$

\title{
"Why Does Google Scholar Sometimes Ask for Money?" Engaging Science Students in Scholarly Communication and the Economics of Information
}

\author{
Scott Warren \\ Syracuse University \\ Kim Duckett \\ North Carolina State University at Raleigh
}

Follow this and additional works at: https://surface.syr.edu/sul

Part of the Library and Information Science Commons

\footnotetext{
Recommended Citation

Warren, Scott and Duckett, Kim, "'Why Does Google Scholar Sometimes Ask for Money?" Engaging Science Students in Scholarly Communication and the Economics of Information" (2010). Libraries' and Librarians' Publications. 78.

https://surface.syr.edu/sul/78
}

This Article is brought to you for free and open access by the Libraries at SURFACE. It has been accepted for inclusion in Libraries' and Librarians' Publications by an authorized administrator of SURFACE. For more information, please contact surface@syr.edu. 
This article was downloaded by: [Syracuse University]

On: 27 April 2012, At: 13:25

Publisher: Routledge

Informa Ltd Registered in England and Wales Registered Number: 1072954 Registered office: Mortimer House, 37-41 Mortimer Street, London W1T 3J H, UK

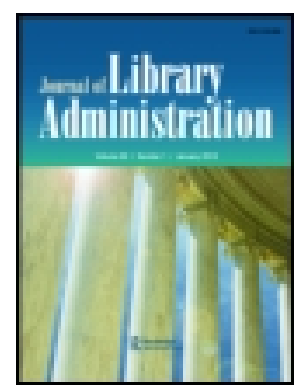

\section{J ournal of Library Administration}

Publication details, including instructions for authors and subscription information:

http:// www.tandfonline.com/ loi/ wjla20

\section{"Why Does Google Scholar Sometimes Ask for Money?" Engaging Science Students in Scholarly Communication and the Economics of Information}

Scott Warren ${ }^{a} \&$ Kim Duckett ${ }^{b}$

a Syracuse University, Syracuse, NY, USA

${ }^{b}$ North Carolina State University, Raleigh, NC, USA

Available online: 20 Apr 2010

To cite this article: Scott Warren \& Kim Duckett (2010): “Why Does Google Scholar Sometimes Ask for Money?" Engaging Science Students in Scholarly Communication and the Economics of Information, J ournal of Library Administration, 50:4, 349-372

To link to this article: http:// dx.doi.org/ 10.1080/01930821003667021

\section{PLEASE SCROLL DOWN FOR ARTICLE}

Full terms and conditions of use: http://www.tandfonline.com/page/terms-and-conditions

This article may be used for research, teaching, and private study purposes. Any substantial or systematic reproduction, redistribution, reselling, loan, sub-licensing, systematic supply, or distribution in any form to anyone is expressly forbidden.

The publisher does not give any warranty express or implied or make any representation that the contents will be complete or accurate or up to date. The accuracy of any instructions, formulae, and drug doses should be independently verified with primary sources. The publisher shall not be liable for any loss, actions, claims, proceedings, demand, or costs or damages whatsoever or howsoever caused arising directly or indirectly in connection with or arising out of the use of this material. 


\title{
"Why Does Google Scholar Sometimes Ask for Money?" Engaging Science Students in Scholarly Communication and the Economics of Information
}

\author{
SCOTT WARREN \\ Syracuse University, Syracuse, NY, USA \\ KIM DUCKETT \\ North Carolina State University, Raleigh, NC, USA
}

\begin{abstract}
This article outlines instructional strategies for teaching students about scholarly communication and the economic realities that surround scientific information. Exposing students to the business side of academic communication provides a foundation for understanding how Google relates to library-subscription resources, how research is both shared and discovered, what the role of libraries is in providing access to costly information, and bow disparities arise in information access. Such instruction contextualizes search tools such as article databases as well as Google Scholar, and thereby serves as an appropriate starting point for teaching students to use such tools.
\end{abstract}

KEYWORDS context-based instruction, critical information literacy, Google Scholar, information economics, information literacy, instruction, journal costs, open access, scholarly communication, science

The authors wish to thank Anna Dahlstein (Syracuse University, formerly North Carolina State University) for providing comments on drafts of this article and her kind assistance in editing. They would also like to thank Daun Daemon, senior lecturer at North Carolina State University, for being the collaborative instructor every librarian hopes for.

Address correspondence to Scott Warren, Bibliographer for the Sciences and Technology, Syracuse University Library, 222 Waverly Avenue, Syracuse, NY 13244-2010, USA. E-mail: sawarr01@syr.edu 
If students really knew how much they were paying for all the info in the library I bet they would definitely be using the library and all of its available resources much more.

— "Graveneworld," anonymous physics graduate student (2007) ${ }^{1}$

It must be acknowledged, that the methods of disquisition and teaching may be sometimes different, and on very good reason undoubtedly; but, for my part, I am convinced that the method of teaching which approaches most nearly to the method of investigation is incomparably the best; since, not content with serving up a few barren and lifeless truths, it leads to the stock on which they grew; it tends to set the reader himself in the track of invention, and to direct him into those paths in which the author has made his own discoveries, if he should be so happy as to have made any that are valuable.

— Edmund Burke, philosopher and statesman (1757, pp. 12-13)

\section{INTRODUCTION}

As the information landscape continues to grow in complexity, it is becoming increasingly important for students not only to be able to locate and access useful information but also to understand the forces that shape the information they consume. To engage thoughtfully with information, they need to learn to pose and answer the following questions:

- Who creates the information I find?

- In what ways has this information been built on prior knowledge and how does it point toward the creation of future knowledge?

- How has this information been debated and vetted by a particular community before making its appearance in the article, journal, database, catalog, or Web site where it was found?

- What economic and technological forces shape how information is constructed and then discovered, shared, stored, and accessed?

This kind of awareness about information is not developed in a vacuum. It is critical for educators-instructors and librarians-to support students as they search for and encounter information and develop the ability to assess these issues critically and independently.

A greater awareness of where information comes from and where it is accessible is important for not only developing the evaluative skills needed to find and make the best use of information, but also to understand the social nature of information and knowledge. Shaping this contextual understanding of information has allegedly always been an aspect of information 
literacy, but in practice it is frequently overshadowed by a skills-based approach that focuses on teaching students how to find, access, and evaluate information. Although centering information literacy around search and evaluation skills remains common, a movement towards "critical information literacy" has begun to emerge. Proponents of critical information literacy advocate teaching how "information' is a social construct created with specific purposes" (Swanson, 2004a) and "highlighting, in addition to the tools and skills metaphor, the importance of learning about context and content in understanding how information 'works"' (Pawley, 2003).

There are many social, cultural, economic, and political facets to how information "works" and many different types of information that students need to learn to find and use in their academic and personal lives. This article focuses on teaching students about peer-reviewed journal literature, certainly one of the types of information most frequently required for the completion of college assignments. It argues that a critical component of teaching students about peer-reviewed articles and how to find them is deconstructing how subscription-based resources such as article databases relate to and complement the search tools that students use more frequently-Google and Wikipedia. To gain a full understanding of what databases are and why they must typically be accessed through an academic library necessitates an investigation of the economic aspects of how information is bought and sold. Moreover, today's powerful public search tools increasingly blur the lines between the free and for-fee zones of the Web. Students stumble onto the porous boundaries between these zones through tools like Google Scholar and Google Books. Meanwhile, Wikipedia and the ease of Web publishing in general call into question the historical authority of formal publication channels and the very nature of what constitutes peer review.

In the past, librarians might have successfully relied on classic dichotomies, such as peer reviewed versus non-peer reviewed or quality resources versus suspect resources, to help students distinguish between subscription-based and free Web resources. Even if they were ever true, however, these dichotomies are moot in the current information landscape, in which powerful search technologies have opened up new access channels to authoritative information (Regalado, 2007). The rise of free Open Access journals, preprint servers, Google Scholar, and Google Books has rendered ineffective the instructional strategy of teaching students that "library" equals "good information" and "free Web" equals "untrustworthy information." As librarians, we know that the the situation is much more complex and we have a responsibility to incorporate this murkier landscape into our instruction.

We believe that a realistic consideration of how library subscriptionbased resources and regular search engines function should center not on simplistic and increasingly inaccurate dichotomies, but rather on these core variables: 
1. Who creates the information and for what audiences;

2. How the information is packaged and distributed;

3. Which technologies and tools are used to discover and access it; and

4. What the economic realities inherent in the preceding factors are.

All of these issues relate to scholarly communication, but with the exception of the first one, they are not commonplace in either the discussion or practice of information literacy instruction. This is especially true of fourth issue, which lies at the heart of the instructional strategies outlined in this article.

While many academic libraries have worked hard to share information about scholarly communication and the economics of information, these efforts almost always target either other librarians or faculty members, though some initiatives have started to reach out to graduate students (for example, Newman, Blecic, \& Armstrong, 2007, the Students for Free Culture movement, ${ }^{2}$ the Scholarly Publishing and Academic Resources Coalition's student advocacy fellow, Nick Shockey, ${ }^{3}$ and most interestingly, the Sparky Awards video contest project $\left.{ }^{4}\right)$. Meanwhile undergraduate students largely remain excluded from the conversation. Although librarians constantly discuss the rising costs of information resources and the ongoing "crisis" in scholarly communication, they seem to overlook the place of such concerns in the information literacy curriculum. What role could such topics play in undergraduate library instruction? The rest of the article outlines why we have come to believe that the economic factors that shape scholarly communication can and should play a salient role in undergraduate teaching.

Recognizing that librarians are primarily practioners rather than philosophers or theorists, the heart of this article consists of a number of instructional strategies we developed for conveying core concepts related to the economics of information and scholarly communication. Our primary "audience" has been students in the physical and life sciences, although some instruction sessions involved their peers in other disciplines, such as art history, textiles, engineering, education, business, and communication. These strategies can be used to situate the "how to search" and "how to find" aspects of instruction in relation to the social and economic forces that shape where one looks for academic information, the tools one uses, and how the library serves as a gateway. Teaching students about academic publishing enables them to see that valuable information frequently comes at a price, a price so high that libraries must necessarily play a role as arbiters of access to expensive information. Furthermore, they begin to glimpse how economic factors affect the development and deployment of technologies that provide access to information on both the restricted and free Web. 


\section{WORKING DEFINITIONS: SCHOLARLY COMMUNICATION AND THE ECONOMICS OF INFORMATION}

This article does not aim to explain why there has been little prior integration of scholarly communication into information literacy (a subject that merits an article of its own), but to explore the possibilities for meshing the two. Suffice it to say that the core communities of those who not only practice, but also write about information literacy and those who write about scholarly communication show little membership in common. Prior to writing this article, we conducted extensive literature searches in Library Literature and Information Science Fulltext, Library, Information Science \& Technology Abstracts, Library and Information Science Abstracts, and Google Scholar seeking to uncover articles addressing both general concerns. No strong overlap between scholarly communication and information literacy was uncovered in the literature. ${ }^{5}$ Even among descriptions of the most innovative programs designed to integrate scholarly communication into the daily practices of librarians, no mention is made of information literacy (Malefant, 2009). However, interest does exist. Discussions and conference meetings with other information literacy and science librarians (A. Colby, personal communication, December 12, 2008; K. Johnson, personal communication, May 6, 2008; L. Kutner, personal communication, March 8, 2008; E. Wallace, personal communication, September, 2008) revealed interest in and similar thinking about the economic contextualization of information. Nancy Linden sought responses on the Engineering Librarians listserv (eldnet-1@u.washington.edu) when she asked

I am teaching a class later today for undergrads ... In doing this in the past, I haven't mentioned the conflict between traditional publishing and proponents of open access. Students always seem puzzled by the fact we pay so much for information that I thought I would like to give them a sense of the issues.

I don't at all want to get into tortuous detail, nor spend a bunch of time, but if there was a way to introduce it to them in an engaging way. ... Has anyone done? [sic] (personal communication, September 23, 2009)

Before proceeding, it is important to clarify that in this context, scholarly communication means how researchers communicate, primarily through the peer review system and journal publishing. Similarly, by economics of information, we refer to the exchange of money that takes place in the creation and dissemination of information. ${ }^{6}$ Librarians are uniquely positioned to demystify how these patterns of scholarly communication and their associated economic costs shape the way libraries and library tools (e.g., article databases and journals) intersect with the free Web. However, it is absolutely 
imperative to understand that teaching students about information economics and scholarly communication practices differs significantly from outreach to faculty on such matters, for the goals are not the same. Our strategies, for instance, do not involve teaching details of various publishing models nor do we advocate particular systems for sustainable Open Access. Instead, our instructional strategies aim to give students a broader context for how peerreviewed, scholarly, and research articles are shaped by social and economic forces that are frequently not explained to them, either in the classroom or the library. Thus our project is pedagogical in nature, not polemical, although students in our sessions often do raise their own questions regarding why journals cost so much, whether this cost has moral ramifications, and what could be done to lessen the economic burdens inherent in the current academic publishing system.

\section{SCHOLARLY COMMUNICATION AND ECONOMICS: FINDING A PLACE IN INFORMATION LITERACY}

Standard 5 of the Association of College and Research Libraries Information Literacy Competency Standards asserts that the "information literate" person understands the "economic, legal, and social issues surrounding the use of information," and that he or she "identifies and discusses issues related to free vs. fee-based access to information" (Association of College and Research Libraries, 2000, Standard 5.1.b). Standard 4 of the American Library Association, the Association of College and Research Libraries, and the Science and Technology Section's Task Force on Information Literacy for Science and Technology (n.d.) similarly highlights the economic, ethical, legal, and social issues surrounding the use of information. Although these highly touted guidelines clearly do mention the economic and social aspects surrounding information, how often are such topics actually covered in information-literacy instruction, much less treated as a substantive part of the lesson plan? Although plagiarism and intellectual property issues (for example, Joint, 2006 and Winterman, 2009) may at times be incorporated into information literacy, there are many "economic, legal and social" issues which are not. How frequently do librarians teach students about the social dynamics at play in scholarly discourse beyond a comparison of the most obvious physical features of a scholarly and popular article? When do librarians engage students in conversations about the high costs of acquiring written accounts of scientific, technological, and medical research? Do librarians help students reflect on why journal publishers can charge so much for peer-reviewed research and why libraries are willing to pay? How do librarians explain to students why they routinely see messages to buy articles when using Google Scholar? Do librarians coach them to wonder if there are social costs accruing as the result of information costs? We suspect 
that all too often librarians merely gloss over those questions, missing an opportunity to challenge themselves and their students. Too often, we leave out "why?" and "why is it this way?" in favor of "how" and "here's what to do." As a result, our instruction can become procedural-more training than teaching.

Over the last decade, several insightful librarians have advocated for a more "critical" approach to information literacy that pushes beyond an emphasis on teaching processes alone (Elmborg, 2006; Fister, 2006; Pawley, 2003; Swanson, 2004a, 2004b). ${ }^{7}$ Proponents of critical information literacy caution that, although standards such as the Association of College and Research Libraries's Information Literacy Competency Standards can help librarians and other educators outline the research process, these standards and performance measures may lead to an excessive focus on teaching skills related to finding, accessing, and evaluating information at the expense of providing insight into how information is intimately tied to the social contexts in which it is created and used. As a result, Swanson (2004b) argues, "before we train students to use search tools, before we send them to books, periodicals, or Web sites, we need to teach them about information. What is it? How is it created? Where is it stored?"

Although information literacy permeates all aspects of life, librarians in higher education are typically asked to provide instructional support to help students understand information in the academic context and, therefore, to gain what Elmborg describes as "academic information literacy ... the ability to read, interpret, and produce information valued in academia" (Elmborg, 2006). Throughout their school lives, students are increasingly initiated into the kinds of thinking, writing, speaking, and presenting valued by academic culture. Although the requirement to find peer-reviewed articles is usually used to steer students toward information viewed by instructors as higher quality, such assignments may also be used to introduce students to how researchers create new knowledge, share it with their peers, and push it out into the world. We believe, however, that the ability to locate disciplinary content alone is not a strong enough foundation for true academic information literacy. Search skills must be accompanied by a greater understanding of how scholarly information is created, debated, vetted, stored, and accessed-issues intrinsically tied to scholarly communication and the economic costs that shape not only the scholarship itself, but also the tools used to discover and access that content. In the contemporary information landscape, simply teaching students how to distinguish peer-reviewed from non-peer-reviewed research is not sufficient. Instead, a broader discussion of scholarly communication and the economics of information will provide a useful, critical framework for learning about how academic research relates to the everyday search tools that students use-Google, Google Scholar, and Wikipedia. 
Moreover, teaching students about the economic realities surrounding information is useful to them beyond the academic context, because it is an important aspect of lifelong learning. Contrary to the popular mantra that "information wants to be free," much of it is not-especially the most highly valued contemporary accounts of research in the science, engineering, technology, and medical fields. Exposing students to this realm of highly priced, specialized knowledge that is not always discoverable or accessible via Google makes it far clearer when and why libraries are needed in the first place. Moreover, teaching students about the exorbitant costs of research literature can set the stage for understanding disparities in access to information around the world. Who else but librarians are well-situated to reveal the socioeconomic disparities that exist in information discovery and access?

\section{BACKGROUND}

Over the past 5 years, we have experimented with systematically incorporating topics, such as the "deep" or "invisible" Web, the nature of scholarly communication, and the inflated costs of academic journal subscriptions into information-literacy instruction. While this process did not unfold all at once, the goal has always been to provide students with a broader context for understanding how scholarly information functions in society, how information is structured on the Web, and what information can or cannot be accessed via Google. This contextualization of academic resources is presented in tandem with hands-on instruction on how to search and access such resources effectively because it is clear that the students do need practical "how-to" training as well. Furthermore, seeing broader contextual issues and principles play out in concrete examples culled from assignment needs helps illustrate the ideas we are attempting to share.

The main sandbox for this work has been a course at North Carolina State University called English (ENG) 333, "Communication for Science and Research." ENG 333 is the perfect context for teaching students about how scientific information creation and publication "works." The focus of the course is on the rhetorical structures, discourse, and writing practices that surround, permeate, and inform the sciences. It is an elective that is commonly taken by junior or senior life and physical science majors at North Carolina State University, with five or six sections taught each semester. Our instructional strategies have also been used with both undergraduate and graduate students in a variety of other courses, in engineering, social sciences, and the humanities. The approach, of course, varies in complexity depending on the sophistication of the audience-ranging from introducing freshmen to the notion that databases cost money to leading doctoral candidates in a "Communication, Rhetoric, and Digital Media" seminar on a detailed exploration of publishing and library costs. 
Nonetheless, ENG 333 remains the heart and soul of the development of this project.

In ENG 333, a little more than half the instruction session is usually spent discussing scholarly communication and economic issues with students. ${ }^{8}$ The remainder of the time is spent on search strategies for finding peer-reviewed literature. In other teaching contexts, a librarian may wish to use only selected portions of the instructional strategies subsequently outlined. In fact, the modular nature of the strategies allows them to be easily incorporated as needed by the course or as they fit with a particular librarian's lesson plan. It takes relatively little time to explain to students what databases and online journals cost or to use the metaphor of the "invisible" or "deep" Web to highlight the distinction between the free and fee categories of online resources.

One of the simplest ways to establish that distinction is to ask students what they believe the difference is between Google Scholar and any expensive library database. 9 Their answers will generally relate to the degree to which the information included in either is scholarly in nature and vetted. The librarian can then catch the class's attention by saying that the most critical difference is roughly $x$ dollars, especially if $x$ is a five- or six-figure amount. The stage is set for discussing why such expensive resources matter, much less even exist. Regardless of which database is used as an example, the goal of this brief but dramatic introduction is to help students understand that the given tool or content is in the library's collections not only because it is scholarly, but also because it costs money and is otherwise unavailable. The idea that some information can remain out of reach not just as a result of bad searching, but because it costs money, is very often a novel concept to students. When the ramifications of that idea begin to sink in, they do not seem to like it very much. As they start to see that access is primarily an economic function, they begin to realize that there is a why attached to using library tools, not just a bow.

\section{OUR INSTRUCTIONAL STRATEGIES}

\section{Engage Students in a Dialogue about Scholarly Communication}

Students vary widely in what they understand about how researchers communicate and practice peer review and how scholarly information is packaged and disseminated. Few instructors shed much light on these processes, instead merely specifying a couple of important journals in their field and telling students to find peer-reviewed articles. No mention is made of the fact that most journals cost a lot of money and therefore are often only available via libraries. No mention is made of the fact that some of them may not be indexed by Google and Google Scholar, at least in a truly comprehensive way. Librarians can step in to fill in the gaps and help students think about 
why journals exist at all and consider what sorts of costs, discovery tools, and access limitations have grown up around them. In fact, because of the broad familiarity they have with academic publishing, librarians in many ways are better prepared than faculty for this sort of instruction. Faculty possess deep content expertise, but rarely share librarians' extensive knowledge of the economic infrastructures surrounding academic information.

\section{ENGAGEMENT QUESTIONS}

- Why would a scientist want to publish her research in a journal rather than on her blog?

- How many of you have had to find peer-reviewed journal articles in the past? What have you figured out about why they are so special?

- How does the peer review process differ from how information is created and reviewed in Wikipedia?

\section{Teaching Points}

- For a researcher, it is crucially important where he or she publishes, not just whether or not he or she publishes.

- In every field of research there are top-tier, middle-tier, and lower-tier journals that vary in how competitive it is to get published in them-just like how colleges vary in how competitive they are to get into.

- Where the researcher publishes impacts his or her career through the scope of readership and exposure of his or her findings, gaining tenure, obtaining grants, and prestige.

- How the peer review process works.

\section{LEARNING RESOURCES}

In response to how frequently students seemed to be largely unfamiliar with the peer review process, the North Carolina State University (NCSU) Libraries developed the Peer Review in 5 Minutes (http://www.lib.ncsu.edu/ tutorials/pr) animation that is available online for any librarian or instructor to use. Wikipedia: Beneath the Surface (http://www.lib.ncsu.edu/ tutorials/wikipedia) was created to help illuminate the behind-the-scenes social construction of information that affects what you read on the public front-end. Although the latter animation only briefly mentions peer review, it provides a useful contrast to scholarly publishing and peer review by outlining the far more collaborative and informal review process that takes place in Wikipedia. (Both videos are also available via the NCSU Libraries' YouTube channel: http://www.youtube.com/user/libncsu.) 


\section{Teach Students How Scholarly Information Is a Business}

Journals cost money. That simple fact is almost never mentioned to students. We suggest that revealing this reality has positive classroom utility. It helps students realize that the library procures expensive journals that students could never hope to afford on their own or, more to the point, access online. Discussing the money surrounding information also helps students make sense of the messages they frequently see to purchase articles when using Google Scholar.

Interacting with students over the years, it has become clear to us that they vastly underestimate the prices of science, technology, and medical journals, and often think the online versions are entirely free. As a result, cost estimates are incorporated into lessons to drive home the realization that journals are commodities and to get at why articles cost so much when discovered through Google Scholar. Our strategy consists of playing a "Price is Right" type of game in which students make guesses on the price of the journal the instructor-who represents the position of an academic journal publisher-is selling to the library. The librarian selects an expensive (fivefigure) science journal (for which the price is publicly available-we are sensitive to nondisclosure agreements) to emphasize the high price tag associated with certain journals. After four or five guesses are put forward by the class, everyone votes on which price they think is closest. Students at this point often ask interesting questions about who gets access (the entire campus, for how long, print, online, or both, etc.). They are generally stunned at the real prices paid for particular journals. Another way to show how much journals cost is simply to share the individual and institutional subscription prices that appear on the inside cover pages of print journals and then pass the journals around for the students to see for themselves. Even the cost of an individual subscription shocks them.

A slightly different take on this exercise can simply be to share the overall collection budget with students, but first asking them to guess how much the library spends on journals, books, and databases. The numbers will likely seem slightly exorbitant to them until the costs of individual journals are revealed as outlined above. Then, suddenly, library expenditures may actually start to seem limited. After looking at some of the prices, data on annual usage for a couple of journals and the per-use cost is explored. This last exercise drives home the point that for most academic journals, the user community is fairly limited, and therefore the cost-per-use figure may be more meaningful to consider than the absolute cost. Students tend to gain a newfound appreciation for the difficult role their library plays in making decisions on what journals to procure for the campus, given a finite budget. They start to see the necessity of having the library manage access on their behalf and grow even more perplexed at journal pricing when they realize 
the usage of a journal may only be in the double digits in a given year at their campus.

A third activity that can be incorporated in addition to or in lieu of those already mentioned is showing Web sites that highlight "sticker shock." The libraries of Vanderbilt University, Cornell University, and the University of California San Francisco all have effective and interesting Web sites that compare journal costs to products students might find desirable (i.e., a new Volkswagen Beetle, a plasma screen television, a diamond ring, a trip to Europe). Seeing a yearly journal subscription compared to a new car clearly emphasizes the message that real money is involved in securing journals for a campus community and that if journals cost that much money, it is quite unlikely that students will be able to get the full contents of such expensive commodities for free via Google or Google Scholar.

Additionally, students are stunned to discover that researchers sometimes pay a page charge for publication in peer reviewed journals. They often express empathy for them since they recognize the tremendous work that goes into scientific research. Conveying this point to students is important because they frequently think that journal costs might be high because researchers need to be compensated for their hard work. It is eye-opening for students to realize that researchers must factor page charges into their grants and that they receive no payment from publishers for producing articles or serving as peer reviewers. ${ }^{10}$ This model stands in stark contrast to publishing in the literary world, which is at least superficially more familiar to them, in which royalties are the norm.

\section{ENGAGEMENT QUESTIONS}

- How much money do you think Journal $X$ costs (e.g., Brain Research, Tetrabedron)?

- How many people on your campus do you think read this journal?

- Should the entire campus population count when journals are priced?

\section{TEACHIng Points}

- Many journals cost much more than any individual user can afford.

- Journals in the science, medical, and technology fields typically cost more than journals in the social sciences and humanities.

- Libraries act as gateways to information and sophisticated search tools like article databases, many of which cost a lot of money.

\section{LEARNING RESOURCES}

- University of California, San Francisco Library (http://www.library. ucsf.edu/help/scholpub/stickershock); 
- Cornell University Library (http://astech.library.cornell.edu/ast/engr/about/ StickerShock.cfm); and

- Vanderbilt University Library (http://www.library.vanderbilt.edu/jcosts/)

\section{Each Article Is Unique}

After students receive the "sticker shock," two questions are posed to them: "How can publishers charge that much?" and "Why are libraries willing to pay that much?" These questions help students realize that publishers can charge their prices because journals are viewed as absolutely intrinsic to academic work; there simply is no substitute. With some classes this idea is taken further, with a discussion of how journals are competing brands (e.g., showing them several organic chemistry journals from different publishers) and how no library can afford to buy every available journal. We also discuss how journals are "scarce commodities" in that each article is irreplicable, making every issue a highly unique item.

With advanced classes or during a particularly good discussion, the distinctions between scarce commodities, monopolies, and inelastic goods can be explored. Journals can be scarce commodities because libraries do not have enough funds to pay for all of them, but they are not necessarily "monopolies" as there are often competing journals in the same academic subfield (e.g., no single journal holds a monopoly on publishing organic chemistry articles). ${ }^{11}$ However, at the intellectual level, each article is sui generis and cannot blithely be substituted for another article; hence each article is, to some extent, a monopoly unto itself. Getting this idea across is important because undergraduate students habitually view articles as fungible with each other. If a journal has a reputation for publishing articles that are perceived as very important and unique, then it can become an inelastic commodity, that is, a commodity for which the price can be raised with no corresponding drop in consumption (or even if there is a drop it leads to no discernable offset in profits for the seller). Ideas like these are not necessary to basic instruction but can be added as the situation demands. They are presented here as optional fodder for discussion.

\section{ENGAGEMENT QueSTIONS}

- How can publishers charge so much?

- Why are libraries willing to pay so much?

\section{Teaching Points}

- Every article is a unique packaging of research. In many cases, it is only published (made available) in a journal and nowhere else. ${ }^{12}$ The unique- 
ness of journal articles and the research they contain makes them very valuable.

- Each journal issue is completely unique-not like most products which can be substituted (e.g., tubes of toothpaste).

- Publishers have control over the packaging and distribution of these unique journals and their content. That gives them power to set the price.

- University researchers want and need easy access to the best research in their fields, creating high demand for certain journals on campus. Librarians work with faculty to make the best decisions on which journals to purchase for research and student needs.

Expose Students to How Google and Google Scholar Work and How Economics Shapes What These Tools Can Reach

The metaphor of the "deep" or "invisible" Web is not uncommon among librarians (Bergman, 2001; Devine \& Egger-Sider, 2009; Hricko, 2002) and it is an ideal framework for positioning Google in relation to library-subscription resources. Using diagrams illustrating the metaphor of the deep Web, we explore how search engines access content on the "surface" of the Web and often point to but cannot directly take you to deeper content. We delineate the "silo" nature of the deep Web (i.e., numerous discrete databases), and begin analyzing the Web in terms of how its "free" and "costs money" sections are simultaneously separated and intertwined. We look at consumer behavior and review how some Web sites used by consumers, such as the Apple Store, iTunes, Expedia, and so on, contain content that is within the deep Web. They are free to search, but accessing (i.e., buying) the products costs money. The salient point in making these comparisons is that students are already familiar with searching specialized silos of information (eBay, Amazon, Travelocity, etc.) and used to paying for products (i.e., the plane ticket, mp3, or book). This free discovery-paid access model is then contrasted with the paid discovery-paid access model of most library databases and e-journals.

Building on the deep Web metaphor, we further explore how Google, through partnerships with publishers, is increasingly blending the "free" and invisible Web through Google Scholar. There is a pressing need for students to understand the difference between discovery and access, and for librarians to be able to articulate it across the different information scenarios that students will encounter. Simply put, Google Scholar is always a discovery tool. Sometimes it appears to act as an access tool as well, if a publicly available version of an article is discovered or if a library's OpenURL resolver is connected to it. But if an article is not archived openly, then Google Scholar in and of itself loses any ability it has to provide access. This reality is more succinctly put to students as 
The publisher's business is to sell information. Google's business is to make information discoverable. Neither one is in the business of paying for you to get the information. That's your library's business.

Once students understand these distinctions, they can better begin to appreciate both why and how OpenURL resolvers exist and function.

\section{ENGAGEMENT QUESTIONS}

- How many of you have seen a message to buy an article when using Google Scholar? What did you do?

- Why do you think you see those messages?

\section{TEAChing POINTS}

- As a Web user, you dip into and out of the deep Web all the time.

- Economics shapes the way our search tools such as Google, Google Scholar, and library-subscription resources work as well as who gets to use them.

\section{LEARNING RESOURCES}

- The authors' diagram for teaching the concept of the deep Web (http://www.slideshare.net/kimduckett/deep-web-diagram);

- Wright, A. (2009, February 23). Exploring a "deep Web” that Google can't grasp. New York Times. Retrieved September 9, 2009, from http://www .nytimes.com/2009/02/23/technology/internet/23search.html?emc=eta1

- LaGuardia Community College's graphic of the invisible Web (http:// library.laguardia.edu/files/images/invisibleweb/surfaceboats.gif)

\section{Help Students Distinguish Between Discovering Information and Accessing It}

As has been previously explained, we make a strong distinction between discovery and access. You can discover or find that something you want exists - a journal article in Google Scholar, an iPod on eBay, a plane ticket on Travelocity-but this discovery does not guarantee that you can access or get it. You must pay for it first—or in the case of journal articles, the library must pay on your behalf. This distinction is crucial for helping students understand not only why they find messages to purchases articles in Google Scholar from publishers, but also why database records do not represent library holdings. If there is one message that we hope these lessons impart, 
it is that discovery does not guarantee immediate online access and that the reasons why are almost entirely economic rather than technological. If students can understand that article and indexing databases are mostly proof of publication, but not proof of ownership or campus access, they can make more sense of the OpenURL resolvers that many libraries have implemented to connect discovery and access back together in a more seamless fashion.

\section{Teaching Points}

- Proof of publication is distinct from access to the information.

- Some tools are for discovering that a publication exists. Other technologies exist for accessing that publication. They work together.

- Publishers offer to sell articles individually because some people who need them do not have access through a library (and, of course, it provides an additional revenue stream).

\section{Balance Teaching Contexts of Information with Hands-on Experiential Learning}

Instruction that exposes the economics surrounding scholarly communication and its impact on the technologies used to find information provides a natural segue into showing students how to use databases, the library catalog, and Google Scholar effectively. As previously mentioned, too often library instruction leaves out the contextual while dealing entirely with the procedural. For truly effective learning to take place, students need to be able to transfer the theory of information economics back to the task at hand-actually finding journal articles. Thus, ENG 333 classroom sessions always include hands-on searching exercises in which students can begin to apply what has just been discussed and see how the principles invoked hold true across any interface or publisher. We continue to make the discoveryversus-access distinction while teaching students to use a variety of search tools available through the library and giving them hands-on experience with article databases, online journals, and the library's OpenURL resolver. With advanced (doctoral) students, the instructional strategies have occasionally been presented in a seminar format without the hands-on learning component.

\section{ASSESSMENT}

We have experimented with a variety of assessment techniques to evaluate how these instructional strategies impact student learning. We have used a presession "knowledge probe" (Angelo \& Cross, 1993) that has focused 
specifically on scholarly publishing and the Web to understand students' existing mental models related to these topics. Additionally, postworkshop feedback indicates that many students find the combination of context about the economics of information and hands-on instruction useful. We have also used online quizzes after the sessions to track student learning in collaboration with Daun Daemon, the primary ENG 333 instructor with whom we work.

Ms. Daemon is deeply committed to engaging her students in discussions of the economics of information and scholarly communication practices. ${ }^{13}$ She currently requires them to participate in online discussion forums within the learning management system after the workshops. She asks questions such as:

- What is your reaction to the cost of journals and databases? What was most shocking to you about the economics of scientific information? Comment on the issue of scientists having to pay journals to publish their work.

- Has your appreciation for our library grown based on what you learned about the costs of journals and databases? Why or why not?

- What are the most valuable search tips you learned in the library session? Do you have other tips you've gleaned elsewhere that might help your classmates?

The students often voice strong opinions about the costs of journals as well as the library's role in paying for them-both positive and negative. Peering into this postworkshop, non-librarian-facilitated discussion opens up a treasure trove of insights into the impact of our instruction on student thinking.

Most recently, students were given a short postworkshop activity 2 weeks after the session. It focused on transference of the instruction about the economics of information to scenarios not discussed during the workshop. Students were asked to reflect on how the price of scientific information might affect access to peer-reviewed research for the following people: (1) the student after he or she graduates; (2) a scientist working in a lab in the nearby Research Triangle Park; and (3) a scientist working at a university in a developing country in Africa.

This activity is particularly valuable because it further helps reify the fact that discovery and access are two distinct functions. Everyone in the scenario has the ability to search Google Scholar. However, not everyone will have the ability to access a document, primarily for economic reasons. Furthermore, the exercise begins to open students' eyes to another aspect of critical information literacy: how information reflects or influences disparities in power. And finally, students may come to value the access that their library provides more dearly as they begin to fathom the cost at which it is provided. 
The majority of students did an excellent job in transferring what they had learned in the workshop to these new situations.

\section{LISTEN TO THE STUDENTS}

Robert Nash (2009), the official university scholar in the social sciences and humanities at the University of Vermont, recently said that

The key is to remember that the most important part of the word evaluation is value. The best way to evaluate the outcomes of meaning-making learning is to ask students themselves what the value of their experience has been.

On that note, perhaps the clearest indication of the impact of adding economics to the information literacy curriculum is to see what students have to say.

Comments from Postworkshop Feedback Assessment (All Personal Communications, 2006-2009)

I thought the most interesting parts of the forum last night were the statistics. For example, I knew that the university spent tons of money of [sic] journal subscriptions, but I didn't know high it was! The same goes for the number of journals out there, I knew there are a lot but 10,000 was it? That's amazing!

I learned the reason Google fails me so often ... I wish this presentation was offered earlier in my college career.

Being a college student $=$ access to a lot of expensive material.

Best library presentation I've been to.

I have a new appreciation for your job and the economics of the library!

\section{Discussion Board Comments From Eng 333-Fall 2009}

I think that the cost of journals and databases, at least the cost of the ones we went over in class, is way too high. I agree that institutions, like NCSU, should have to pay more than an individual for a subscription since more people will be using the journals/databases they have bought subscriptions for. However, $\$ 23,000$, or even $\$ 10,000$, is too much. 
I think I appreciate the library and what it provides for students and staff more so [sic] now that we've been shown where their money goes. I would have never thought that scientific journals could cost so much money and I appreciate the fact that the library knows how valuable journals are as resources for everyone on campus and has them available for us to use in and out of the library.

-Junior, Meteorology

It seems almost like textbooks. They (the publishers) know people need it so they charge the most they can get for it. Yes the journals have unique information and no 2 articles are the same, but some are very similar just like former editions of textbooks. If there were only a few journals, I can understand 20,000+ price tags, but there are hundreds of thousands of journals.

\section{—Senior, Biochemistry}

The most shocking thing to me about the economics of scientific information is the cost to the scientist. Not only does a scientist have to go through an extensive, and likely very stressful, peer review process in order to have his/her work published, but to have to pay a large sum of money per-page to be printed on top of such a process is a lot.

$$
\text { -Junior, Meteorology }
$$

Where is the basic law of economics here? I don't understand why there is not more competition if the publishing companies are truly making that much profit. To increase subscription costs 215\% between 1986 and 2003 is ludicrous!! Why wouldn't more entrepreneurs enter this business?

—Senior, Animal Science

\section{CONCLUSION}

So where do we go from here? Further and more granular assessment is needed to discern just which aspects of our efforts have met with the most success and which topics remain most opaque to students. More assessment is also needed to determine which ideas transfer most readily to productive and desired learning outcomes and which remain, while interesting, essentially academic or theoretical considerations. The extensive sets of pretest and posttest data we have collected may ultimately be able to form the basis for a future article based on an analytical treatment of said data.

As mentioned in the introduction, the primary focus of our work has been teaching students about peer-reviewed journal literature by harnessing 
the high pedagogical value of viewing subscription-based resources and how they function through an economic lens. These ideas are pursued primarily to aid students in using the tools and resources provided by libraries, not to sway them towards favoring any particular ideology or business model regarding Open Access. Nonetheless, we believe that these practices hold merit not only toward improving information literacy, but also toward broadening libraries' outreach efforts in the realm of scholarly communication. Most students simply have no idea that information is a commodity. Nor do many graduate students or even faculty realize that the expenditures for discovery and access may be separate line items within a library's collections budget.

It has been suggested that information, or at least academic information, should become a public good and not a commodity (Courant, 2006 ${ }^{14}$ ) and we recognize that we may therefore tread on slippery ground by focusing so heavily on the academic library as a provider of expensive, toll-based information. While we subscribe to the general principles of Open Access, the fact is that at the present moment, most academic information, especially that assuming the form of articles in peer-reviewed journals, remains a commodity. The needs of students, especially undergraduate students, are firmly planted in the here and now. Therefore, advocating for change does little to help them understand the contexts of the information they need for academic success today. However, some of these students will go on to pursue careers in academia. We believe that inculcating an early awareness of the costs of scholarly information, the roles libraries play in this landscape, and the complex ethical questions swirling around access and provision may help the Open Access movement thrive in the long-run.

Ultimately, we do not agree with the commonly held view that information literacy efforts are about education and scholarly communication outreach is about action. True learning requires first reflection and then action. Nash argues that "Performance is mainly about acquisition, storing information, and taking tests. Learning is developmental and an end in itself" (2009); a statement which prompted Fister's (2009) thoughts on the role of librarians in teaching and learning:

I think that's actually our best argument for academic libraries and for giving students a chance to learn in them ... not learn how to manipulate the tools, but to be actively seeking, sorting, sifting, and making meaning as a central part of their education. If we want to define information literacy, we need to make it clear that practicing it-exploring ideas independently — is a big part of the high-impact practices that we know make learning stick.

And in the meantime, maybe we can also reflect on our own teaching practices. Can we teach less to make more room for learning. ... Can we put the focus on not just learning how the library works [we believe she 
means using tools here] but learning where knowledge comes from and how it's made?

At the point of need, teaching students skills for discovering and then accessing information is the priority. In the medium term, however, teaching them about the forces that shape discovery and access to give them a contextual understanding that tranfers across any kind of information platform is more significant. It has a greater pedagogical impact on the students, not just for their current academic needs but also for their lifelong learning.

This project has potentially even broader ramifications. It is crucial to expose students to the structural considerations and power dynamics that underlie contemporary academia and the associated industries that aid its massive production and consumption of information. Doing so gives these future citizens and scholars the ability to evaluate such systems from moral and ethical stances of their own choosing. Thereby, they may well take a greater interest in how our shared academic information ecology unfolds in the 21 st century. Undeniably a lofty goal, this objective transcends the necessary (and still important) role that librarians play in the day-to-day tasks related to helping students locate information. However, we believe that this higher aspiration is what is truly implied by the Association of College and Research Libraries (2000) and the American Library Association, the Association of College and Research Libraries, and the Science and Technology Section's (n.d.) standards that challenge librarians to tackle the ethical, legal, and social dimensions of information.

\section{NOTES}

1. This quote is taken from the Physics Forum discussion board: http://www.physicsforums.com. "Graveneworld's" quote comes from his 11:17 AM post, which is not his first post in the exchange in the discussion thread labeled "Students this is why you should use the library" (http://www.physicsforums.com/showthread.php?t=183796).

2. See http://wiki.freeculture.org/Open_University_Campaign

3. On September 30, 2009, Shockey (2009) gave a Webinar entitled "The Next Level of Student Engagement: Open Access Week and Beyond," which dealt with "new ways to get student attention-including new messages and tools he's developed, how to connect to the burgeoning student network for Open Access, and how to plug in to the student initiative for Open Access Week."

4. http://www.sparkyawards.org/

5. A final search was done in Library and Information Science Abstracts (LISA) on September 28, 2009 (2 days before this article was submitted) on the thesaurus terms scholarly communication and information literacy (literally DE [descriptor] = (information literacy" and "scholarly communication")). Zero hits were found, meaning that no articles were considered strongly enough about both topics as of that date to warrant both controlled vocabulary terms. For comparison, 519 results were found for DE = "scholarly communication" and 2097 results for DE = "information literacy."

6. It has been suggested to us that what we mean by eonomics is really the day-to-day business practices of the library world. For lack of a better term, we will continue to use the word economics with the clear understanding that it means money changing hands over academic information.

7. For an extensive set of definitions of information literacy, see Snavely and Cooper (1997, p. 11). While older, this article is fascinating for several reasons. It sums up arguments for and against using 
the term information literacy in lieu of older terms, such as bibliographic instruction or library skills. As we both began our library careers in 2001, the dust had already settled on that argument, and the term information literacy has always been the accepted parlance in our work. Nonetheless, Snavely and Cooper do touch on concerns we share when they note that "The word skills implies that mastering a precise set of routines will take care of the learning, and does not imply a greater engagement or involvement with the material." Indeed.

8. From 2002-2003 Scott Warren worked alone on ENG 333. From 2004-2008 we worked together on teaching sessions for the course, including distance-education sections. After Scott Warren moved from North Carolina State University to Syracuse University in the summer of 2008, Kim Duckett continued (and continues) to work on ENG 333.

9. Pricing information is only passed on verbally and in accordance with license agreements. Ballpark figures are sometimes used rather than exact amounts.

10. We acknowledge that editorial duties are sometimes remunerated.

11. It can be argued that collectively, academic publishers do hold a near monopoly on access to highly coveted research results-at least until any of the various Open Access models gains more substantive traction.

12. The astute reader will immediately note that according to Sherpa-Romeo (2009), about $29 \%$ of publishers now permit green archiving (putting both the preprint and postprint versions of an article into a repository with another $21 \%$ allowing postprint versions to be deposited and $11 \%$ allow preprint archiving only. These numbers aggregate to $61 \%$ of publishers allowing self-archiving of some form of an article and were valid as of September 25, 2009. See http://www.sherpa.ac.uk/romeo.php?stats=yes.

Thus many articles can now, in theory, be accessed via channels other than the publisher's payper-view site. But since the vast majority of institutions or disciplines do not possess a repository and self-archiving via faculty Web pages is extremely hit-or-miss (Poynder [2009] estimates only "15\% of research is being self-archived by authors"), many articles in practice are not directly available online except via the publisher.

13. In fact, Ms. Daemon won the 2008 NCSU Libraries Faculty Award for her ongoing commitment to and engagement with the libraries.

14. See also Cantor (2007) for a more extensive argument on all higher education as a public good as viewed through the developments occurring at Syracuse University.

\section{REFERENCES}

American Library Association, Association of College and Research Libraries, \& Science and Technology Section Task Force on Information Literacy for Science and Technology. (n.d.). Science IL standards and teaching ideas. Retrieved September 15, 2009, from http://wikis.ala.org/acrl/index.php/ Science_IL_Standards_and_Teaching_Ideas

Angelo, T. A., \& Cross, K. P. (1993). Classroom assessment techniques: A handbook for college teachers. San Francisco: Jossey-Bass.

Association of College and Research Libraries. (2000). Information literacy competency standards for higher education. Retrieved September 15, 2009, from http:// www.ala.org/ala/mgrps/divs/acrl/standards/informationliteracycompetency.cfm

Bergman, M. K. (2001). White paper: The Deep Web: Surfacing hidden value. Journal of Electronic Publishing, 7(1). Retrieved September 15, 2009, from http://www.journalofelectronicpublishing.org

Burke, E. (1757/1990). A philosophical enquiry into the origin of our ideas of the sublime and beautiful. New York: Oxford University Press.

Cantor, N. (2007, January 23). Scholarship in action and the expansive mission of higher education (Address to the campus community). Retrieved Sepember 23, 2009, from http://www.syr.edu/chancellor/speeches/1_07_address.pdf

Courant, P. (2006). Scholarship and academic libraries (and their kin) in the world 
of Google. First Monday, 11(8). Retrieved August 10, 2009, from http:// firstmonday.org/htbin/cgiwrap/bin/ojs/index.php/fm/article/view/1382/ 1300

Devine, J., \& Egger-Sider, F. (2009). Going beyond Google: The invisible Web in learning and teaching. New York: Neal-Schuman.

Elmborg, J. (2006). Critical information literacy: Implications for instructional practice. The Journal of Academic Librarianship, 32(2), 192-199.

Fister, B. (2006, March 21). Making information literacy critical. Retrieved from http://acrlog.org/2006/03/21/making-information-literacy-critical

Fister, B. (2009, September 22). Not about technology, not about teaching. Retrieved from http://acrlog.org/2009/09/22/not-about-technology-not-about-teaching/

"Graveneworld" (anonymous grad student). (2007 September 10, 11:17 AM). Students this is why you should use the library. Physics Forums. Retrieved from http://www.physicsforums.com/showthread.php?t=183796

Hricko, M. (2002). Using the invisible Web to teach information literacy. Journal of Library Administration, 37(3/4), 379-386.

Joint, N. (2006). Teaching intellectual property rights as part of the information literacy syllabus. Library Review, 55(6), 330-336.

Malefant, K. (2009). Leading change in the system of scholarly communication: A case study of engaging liaison librarians for outreach to faculty. College and Research Libraries, 71(1), 63-76. Retrieved from http://crl.acrl.org/ content/71/1/63.full.pdf + html

Nash, R. (2009, September 22). Resist the pedagogical far right. Inside Higher Ed. Retrieved September 23, 2009, from http://www.insidehighered.com/ views/2009/09/22/nash

Newman, K. A., Blecic, D. D., \& Armstrong, K. L. (2007). Scholarly communicaton education initiative (Spec Kit 299). Washington, DC: Association of Research Libraries.

Pawley, C. (2003). Information literacy: A contradictory coupling. Library Quarterly, 73(4), 422-452.

Poynder, R. (2009, September 26). Compact for open-access publishing equity: Mistaking intent for action? Retrieved from http://poynder.blogspot.com/2009/09/ compact-for-open-access-publishing.html

Regalado, M. (2007, June). Research authority in the age of Google: Equilibrium sought. Library Philosophy and Practice. Retrieved August 5, 2009, from http://www.webpages.uidaho.edu/ bolin/regalado.htm

Sherpa-Romeo (2009). Publisher copyright policies \& self-archiving. Retrieved September 18,2009, from http://www.sherpa.ac.uk/romeo.php?stats=yes

Shockey, N. (2009, September 30). The next level of student engagement: Open access week and beyond. Retrieved from http://www.arl.org/sparc/media/ 09-0917.shtml

Snavely, L., \& Cooper, N. (1997). The information literacy debate. Journal of Academic Librarianship, 23(1), 9-14.

Swanson, T. A. (2004a). Applying a critical pedagogical perspective to information literacy standards. Community \& Junior College Libraries, 12(4), 65-77.

Swanson, T. A. (2004b). A radical step: Implementing a critical information literacy model. Portal: Libraries and the Academy, 4(2), 259-273. 
Winterman, B. (2009). Building better biology undergraduates through information literacy integration. Issues in Science and Technology Librarianship, 58. Retrieved September 28, 2009, from http://www.istl.org/09-summer/ refereed1.html

Wright, A. (2009, February 23). Exploring a 'deep Web' that Google can't grasp. New York Times. Retrieved July 9, 2009, from http://www.nytimes.com/ 2009/02/23/technology/internet/23search.html?emc=eta1 